\title{
AMMATTIKORKEAKOULUN HYVÄ JA PAHA
}

FRIMAN, MERVI, LAMPINEN, OSMO, NUMMELA PEKKA \& VOLANEN MATTI VESA (toim.) Ammattikorkeakouluetiikka. Opetusministeriön julkaisuja 2004: 30.

Teoksen nimi herätti kysymyksen, onko ammattikorkeakoululla oma etiikkansa ja jos on, kenen tai keiden etiikasta oikeastaan on kysymys ja miten se määrittyy. Teoksen 18 kirjoittajaa vastaavat kysymykseen kukin omalla tavallaan. Artikkeleissa kuuluu eri alojen tutkijoiden ja opettajien sekä koulutuksen ja työelämän asiantuntijoiden ääni. Kirjan tarkoituksena on tuoda esille eri näkökulmista nousevia eettisiä, filosofisia, ja pedagogisia haasteita ammattikorkeakoulujen omaan kehittämistyöhön (s. 12).

Yhtenäistä eettistä normistoa ammattikorkeakoulujen toimintaperiaatteille ei kirjasta löy- dy. Sen sijaan teos avaa paikoitellen ansiokkaastikin ammattisivistyksen ja hyvän ihmisen ideaaleja sekä herättää eettistä pohdintaa. Kirjoittajien pohdinnat ulottuvat laajemmalle kuin teoksen hieman kapea-alaiselta kuullostavasta nimestä voisi päätellä.

\section{MONIÄÄNISYYS MYÖS HAJAUTTAA}

Toisaalta moniäänisyys antaa etiikasta käsitteenä ja ilmiönä melko hajanaisen kuvan, ja joissakin artikkeleissa eettisten kysymysten tunnistaminen jää pinnalliseksi. Jäin kaipaamaan kokoavaa katsausta siihen, miten etiikka teoksessa ymmärretään. Eettisyydestä puhutaan $\mathrm{mm}$. vastuullisuutena, joka puolestaan edellyttää autonomiaa. Autonomia ilmenee mm. instituution vapautena markkinavoimien ohjauksesta ja valtion tiukasta säätelystä sekä toisaalta yksilön vapautena aitoihin valintoihin ja omien prioriteettien asettamiseen. Lisäksi asetetaan runsaasti eettisiä ideaaleja ja normeja eri toimijoille. Enemmän olisi voinut painottua se, millaisin edellytyksin koulutusinstituutioiden ja työyhteisöjen jäsenet voisivat pohtia omaa etiikkaansa aidon reflektiivisesti sekä arvioida toimintakulttuuriaan ja päämääriään.

Osa kirjoittajista puhuu eettisen toiminnan ideaaleista kollektiivisen instituution tai yrityksen äänellä. Esimerkiksi ”...ammattikorkeakoulut joutuvat tekemään arvovalintoja...” ja niiden "... tulee olla myös aktiivinen yhteiskunnallinen muutosagentti hyvän työelämän, hyvän yhteiskunnan, hyvän ympäristön ja hyvän elämän edistämiseksi” (Lampinen \& Nummela, s.11-12). Yrityksiltä puolestaan edellytetään yritysetiikkaa ja yhteiskuntavastuuta. 
YKSILÖLLISIÄ ÄÄNIÄ

Useimmista artikkeleista löytyy kuitenkin myös yksilöllisiä toimijoita eli ajattelevia ihmisiä, jotka voivat ottaa vastuun toiminnan eettisyydestä - tai toisaalta jättää sen tekemättä. Esimerkiksi Risto Honkosen ja Timo Koranderin artikkelissa konkretisoituu eri professioiden ammattietiikoiden erilaisuus ja niitä edustavien toimijoiden eettiset ristiriidat. Eettisten näkökulmien erilaisuus on merkityksellistä erityisesti moniammatillisessa yhteistyössä. Eettisten ristiriitojen näkyväksi tekeminen yleensäkin selkeyttää keskustelua arvoista ja etiikasta ja niiden merkityksestä toiminnan kannalta.

\section{EETTISYYDELLÄMYÖS SIVISTYSNÄKÖKULMA}

Ammattikorkeakoulun arvoperustaa tarkastellaan mm. sivistyksen käsitteen kautta. Eettisyys nähdään ammattisivistyksen keskeisenä ehtona. Myös yliopiston ja ammattikorkeakoulun suhdetta valotetaan sivistyksen näkökulmasta. Sami Pihlström katsoo, että ammattisivistyksen luonnetta ja ammattikorkakoulujen tehtävää voidaan ymmärtää deweyläisen pragmatismin kautta, jossa tieto ja käytännön toiminta kiinnittyvät toisiinsa. Deweyn naturalismin mukaan maailmassa oleminen nähdään ihmiselle tyypillisenä tapana tulla toimeen ympäristössään. Myös Aristoteleen hyve-etiikan pohjalta käytännöllisyys (praxis) voidaan ymmärtää maailmassa olemisena, jatkuvana suhteena toiseuteen ja tulevaisuuteen. Siten ammattikorkeakoulun toiminnan lähtökohdat voisivat Mervi Frimanin mukaan olla elävästä elämästä nousevassa ymmärryksessä, johon sisältyy myös eettisten kysymysten tunnistaminen ja pohtiminen.

Rajanveto tiedekorkeakouluihin nähden jää teoksen pohjalta epämääräiseksi eikä sen tekeminen ole kai tavoitteenakaan. Esimerkiksi Pihlström korostaa tutkimukseen perustuvaa opetusta ja kriittisen ajattelun taitojen kehittämistä kaikkien korkeakoulujen ihanteina. Selkeän erottelun vaikeus tiede- ja ammattikorkeakoulujen välillä johtunee mm. siitä, että eri tieteen- (ja taiteen)aloilla on kovin erilaiset käsitykset tiedon luonteesta, oppimisesta ja asiantuntijuudesta yliopistojen sisälläkin. Siksi jotkin kirjassa esitetyt yleistykset yliopistojen tiedon- ja oppimiskäsityksen luonteesta eivät ole perusteltuja.

Myös alueellinen eriytyminen epäyhtenäistää yliopistojen tavoitteita ja tehtäviä. Erityisesti yliopistojen ns. kolmas tehtävä eli ympäröivän yhteiskunnan kehityksen tukeminen lähentää ammattikorkakoulujen ja yliopistojen tehtäväkenttää sekä tuo esiin yhteisiä eettisiä ja yhteiskunnallisia ongelmia mm. tutkimusrahoitukseen liittyen (ks. Panu Raatikainen). Yhdistäviä asioita ovat useat eettiset peruskysymykset, kuten tutkimusetiikka ja tutkijan vastuu sekä pohdinnat tieteen arvovapaudesta. Tosin Osmo Lampinen (s. 23) hieman yllättävästi väittää, että tutkijalla ei yleisesti ottaen olisi vastuuta tutkimustulostensa käytöstä kuten ammattikorkeakoulujen kasvattamilla asiantuntijoilla on. Näin ollen ammattikorkeakouluilla on hänen mielestään suurempi moraalinen vastuu kuin yliopistoilla.
EETTISYYS JA

\section{ASIANTUNTEMUS}

Keskustelussa asiantuntijuudesta unohtuu usein eettinen näkökulma. Teos avaa asiantuntijuuden käsitettä arvo-osaamisen ja eettisen vastuullisuuden suhteen mielenkiintoisesti. Ammatillinen sivistys ja asiantuntijuus edellyttävät paitsi ammattien eettisten normistojen tuntemista, myös yksilön henkilökohtaista etiikkaa. Hyvän ihmisen ja ammatillisen asiantuntijan ideaaleja tarkastellaan mm. teologisen kutsumusajatuksen ja antiikin hyveellisyyden ideaalien kautta. Aristoteleen hyve-etiikassa ihmisen luonteen hyveisiin yhdistyy parhaimmillaan käytännöllinen järkevyys (fronesis), joka ei sulje pois myöskään emotionaalista herkkyyttä. Kasvattajan tehtäväksi määrittyy käytännöllisen järjen opettaminen sekä hyveellisyyden mielekkyyden osoittaminen omassa toiminnassaan. (Friman, s. 137-139.)

Sijansa saa oikeutetusti ammattietiikan opetuksen tarkastelu sekä ammatillisiksi opettajiksi opiskelevien eettisen ajattelun ja kasvatustietoisuuden kehittyminen. Ilma Tahvanaisen mukaan opettajan eettisyys ilmenee nimenomaan kasvatustietoisuutena, joka edellyttää kasvatuksellisten tekojen laadun ja merkityksen pohdintaa. Kasvatuksellinen toiminnan ehtona nähdään kasvatussuhteessa oleminen. Lisää eettisiä vaateita opettajuudelle lisäävät yhteiskunnallinen muutos, globalisoituminen ja opettajan autonomian lisääntyminen. Uhkana näyttäytyy sekä ammatillisuuden että kasvatuksellisuuden häviäminen ammatillisesta opettajuudesta ja opettajuuden redusoituminen opetusteknis- 
ten innovaatioiden tuottamiseen (ks. Friman, s. 142, Pihlström, s. 59, Tahvanainen, s. 159). Konkreettisena ehdotuksena teoksessa perätään entistä suunnitelmallisempaa ammattietiikan opetusta.

Teoksessa korostuu työelämän yksipuolisten tehokkuusideaalien ja markkinavoimien säätelemän toiminnan kriittinen tarkastelu. Niihin liittyvien eettisten epäkohtien kautta perustellaan työelämän muutoksen tarvetta ja ammatillisen korkeakoulutuksen hyveellisiä päämääriä. Sen sijaan ammattikorkeakoulun omien toimintakulttuurien arviointi jää melko vähäiseksi, vaikka teoksen nimestä voisi toisin päätellä. Esimerkiksi ammattikorkeakoulun historiallista kehitystä valottava artikkeli olisi voinut antaa pohjaa instituution rakenteiden ja käytäntöjen kriittisemmälle arvioinnille. Toisaalta kirjasta löytyy jonkin verran myös ammattikorkakoulun toimijoiden itsekriittistä pohdintaa, mikä lisää teoksen vakuuttavuutta. Jäin kuitenkin miettimään, kenelle kirja on oikeastaan kirjoitettu. Jossain määrin se epäilemättä palvelee ammattikorkeakoulun sisäistä kehittämistä, mutta samalla näkyy pyrkimys selkeyttää instituution asemaa ja roolia ulkopuolisille. Jälkimmäisellä tavoitteella ei paikoitellen näytä olevan kovinkaan paljon tekemistä etiikan kanssa. Teoksessa ilmenevä "hyvän ja pahan” erittely voi kuitenkin palvella molempia tavoitteita.

Ammattikorkeakoulun etiikan uhkina nähdään siis markkinaperustaiset arvot, liike-elämän ohjaus ja opiskelijan ”redusoituminen työelämän toi- mijaksi”. Ideaaleiksi ja päämääriksi nousevat puolestaan akateeminen vapaus ja institutionaalinen autonomia sekä niihin liittyen toimijoiden mahdollisuus ja valmius kriittiseen ja eettiseen ajatteluun. Opiskelijan kasvun päämäärinä nähdään hyvään ammatillisuuteen liittyen kansalaisuus, lähimmäisyys sekä kumppanuus, ja lisäksi pyrkimyksenä on "kytkeä opiskelijoita tieteellisen tutkimuksen ja sivistyksen perinteeseen, totuuden ja hyvän elämän etsintään” (Pihlström, s. 59). Tällä tiellä professioiden ja ammattikuntien eettiset ohjenuorat nähdään tärkeänä, samoin kuin eettisten ideaalien ja reflektiivisyyden näkyvyys ammattikorkeakoulun opettajien omassa toiminnassa.

\section{Sirpa Törmä}

